\title{
Stock Liquidity and Real Economic Activities-Evidence from Karachi Stock Exchange
}

\author{
Hubab Zia \\ Research Scholar \\ Karachi University Business School, University of Karachi, Pakistan \\ Dr. Danish Ahmed Siddiqui \\ Associate Professor \\ Karachi University Business School, University of Karachi, Pakistan
}

\begin{abstract}
Stock markets play a significant role for investors and financial institutions and help them to in order to mobilize their finances and provide platform to buy and sell their stock. In any country stock market has a significant effect on the economy as it regulates money and debts. This helps in focusing on the allocation of our investment and resources efficiently. This further enhances the structure of stock market and guide future direction for investment opportunities. Equity market is considered as a source of capital for the investors and financial organizations. The aim of our is to investigate the Karachi stock market liquidity using firm level data describing the real economic activity of the country by controlling equity and non equity factors. For this purpose, alternative liquidity proxies are applied to economic indicators by taking the stock sample from KSE during the tenure of last years (1988-2018). The tools for measuring illiquidity measures Amihud (ILR) and the relative spread (RS) were used whereas Turnover (TUR) and the volume of trading (VTR) are used to measure liquidity. The sample for this study consists of firms' stocks listed on the Karachi Stock Exchange for calculating the liquidity proxies and real economic activity, daily stocks prices data and returns, total number of shares and trading volume of each company. For measuring real economic activity the macro variables used are: Real GDP (RGDP), Real consumption (RC), Real investment (RI) and the unemployment rate (UnR). Hypotheses were developed according to the objective of the study. Standard linear and nonlinear models for the GDP calculation and regression model for developing the correlation between stock market liquidity and various economic factors. Jarque-Bera test, causality tests were applied to find correlation between stock market liquidity and real economic activity factors. The result of this study suggested that stock market liquidity has a significant effect on real economic activity in Karachi stock exchange market.
\end{abstract}

Keywords: Stock market, liquidity, illiquidity, economic activity, capital, investment,

DOI: $10.7176 / \mathrm{EJBM} / 11-10-02$

Publication date: April $30^{\text {th }} 2019$

\section{Chapter 1: Introduction}

\subsection{BACKGROUND TO THE STUDY}

Stock markets are considered as key players in providing investors and financial institutions to mobilize their capital and provide an alternate market to buy and sell their stock. During last three decades, the Stock markets have accomplished to gain investors, policy makers and investors confidence. Stock markets have a successful history in making countries expand their capital markets to compete with international economies. Just like in other markets, even in Karachi Stock Exchange which is one of the mature markets of Pakistan, stock market liquidity is an effective tool to determine the market efficiency. Large transactions are processed within a stock market makes a market more liquid (Blanchflower, and Oswald, 2013).

An investor always invests in a business with the aim of earning high returns and profits. Investors are always on a hunt for good opportunities of investment. The first and the foremost importance is given to the liquidity of their investment portfolios. In secondary market they look for liquefying their financial assets at stock exchanges. Therefore, the factor of liquidity has become a significant factor of stock returns. There have been debates regarding the relationship between liquidity and stock return as to whether the relationship between these two variables is positive or negative. According to Leirvik, Fiskerstrand, \& Fjellvikås, (2017) liquidity is divided into two parts: market liquidity and funding liquidity. Market liquidity is related to the choice of traders when and where they wish to trade financial assets whereas funding liquidity is the ease of credit accessibility and they both are linked with each other.

For any nation stock market affects the economy as it regulates money, debts but public trades are not imposed. Businesses get a chance to continue public trade and improve the financial capital thorough selling of shares. During the recession phase of stock market of Pakistan, the stock price index fell down drastically in 2008 and crashed to 6000 points from 14000 points. Such statistics can give a major blow to any economy and this happened in Pakistan as the liquidity in trading stock got severely affected and investors were compelled to 
lose their stocks.

In Pakistan, Karachi stock exchange is one of the vital stock markets. The KSE was founded in 1947 and KSE 100 index was initiated in 1991 in which top 100 best performing companies were selected on the grounds of their capital. Like any other market, in KSE liquidity is considered as an important feature as it affects stock returns (Amer Al-Jaifi, Hussein Al-rassas, \& Ali AL-Qadasi, 2017). Level of liquidity in any financial market is an important issue as high liquidity in stock market could result in the economic growth of the country. According to Leirvik et al., (2017) liquidity can be measured through various measures and every investor has the aim of converting of assets into cash. In emerging markets illiquidity becomes a reason for apprehension of investors and the implications of liquidity is of importance. In emerging markets, macro economic factors can pose challenges and result in increasing commonality in liquidity because alternative options for investment are seldom available. Therefore, the investors who are facing liquidation needs donot have options to branch out their liquidity shock henceforth, co-variation in liquidity occurs in a single asset market.

\subsection{PROBLEM STATEMENT}

As we know that due to economic downturns by the recent government of Pakistan, many industries both large scale and small scale are suffering as trading has been minimized or over-regularized by the government. In the last few months we have seen the trappings of a liquidity crisis form due to the melt down of the mortgage markets that is now affecting much of the credit markets in particular and capital markets in general. This phase in Pakistan is affecting stock markets equally as the connection lies among the variables. Investors are becoming fearful and reluctant that their owned assets are losing value, so they are selling stocks to generate the capital to meet the demands of investor's. This caused the increase in volatility we are experiencing in the Pakistan stock markets (Cakici and Tan, 2014). According to liquid shock hypothesis when assets market liquidity falls due to any reason it affects equity prices and liquid asset prices. Equity prices drop down and liquid asset prices increase. The impact of this reduction in equity prices is quite negative as companies are already facing financial challenges on investments because it decreases the ability of firms to raise funds through keeping equity as collateral for borrowing purpose. This marks the start of a recession because the investment opportunities diminish and the output is not up to the mark (Florackis et al, 2014b). Such conditions are not favorable for developed countries and the impact on developing countries could not even be imagined. In developing countries investors invest both in small and large cap firms to diversify their capital and increase marginal profit as their economies are highly volatile and illiquid. This drives researchers to shed more importance on determining correlation between stock market and economic factors which is very important for Pakistan. Therefore, a need is felt to provide a deep insight to reveal the correlation of stock market liquidity and economic activity on firmlevel data for attracting foreign investors and gain confidence of local investors back.

\subsection{GAP ANALYSIS}

There are several studies that are conducted on aggregated stock markets of countries with different origins which aim at determining impact of factors like country's income level and size of the market (Florackis et al, 2014a). Many researchers are focused on investigating the stock market liquidity patterns that are impacted by the economic factors on a country level individually. Rehman, Mahdzan, and Zainudin (2016) investigated the impact of macroeconomic variables on stock market liquidity in emerging market during 2000 to 2014 . They used Granger causality test and IAA (innovative accounting approach) to check the causality with the variables of interest. Their result shows that on market liquidity in the short-run, interest rate, monetary base and foreign equity new influx had lagged effect. Furthermore, the causality test suggests stock market liquidity is only affected by foreign equity and industrial production. Their research was limited to only liquidity and did not illiquidity. Another study by Sharif and Afshan, (2016) was conducted in Pakistan to analyze how economic growth is impacted by development of stock market in the country. They carried out their calculations on quarterly data from Q1:2002 to Q4:2011using the OLS regression method on IPI which was taken as the dependent variable whereas the predictors of the study were stock price index, market capitalization and stock returns. Their results indicated that all the three variables contribute significantly and positively in predicting the economic growth.

Apergis, Artikis, Kyriazis (2015) conducted a study to check if Stock Market Liquidity Explain Real Economic Activity by comparing two European Stock Markets i.e. UK and Germany. Their aim was to check the behaviour of stock market liquidity in a bank-based system (Germany) and a market-based system (U.K.). They used four liquidity measures the Amihud (2002) illiquidity ratio (ILR), the relative spread (RS), turnover (TUR) and the volume of trading (VTR). For economic activity macro variables used were real GDP (RGDP), real consumption $(\mathrm{RC})$, real investment $(\mathrm{RI})$ and the unemployment rate (UnR). It was found that UK market is more liquid than German market. For checking the impact Instrumental Variable (IV) methodological approach was adopted and causality test, Q test, Jarque bera test, Wald test were performed. It was found that market liquidity is related to economic growth in both the countries. 
However, above mentioned studies have taken into account the correlation and association between liquidity of stock market and macro-economic variables are limited to developed countries. Therefore in developing countries like Pakistan, this association needs to be researched using methodological approaches, market selection and sample period to categorically understand this relationship. Our study contributes to fill this research gap Therefore, in order to assess the stock market liquidity in other markets which are more volatile, we took Karachi Stock Exchange (KSE). Pakistan's small and large cap firms that are listed in KSE and it makes a huge market capitalization which subsequently explains larger effects of liquidity.

\subsection{Research Objectives and Significance}

The objective of this study is to investigate the Karachi stock market liquidity using firm level data that describes the economic activity when the number of equity and non equity factors are controlled. In order to achieve this objective, alternative liquidity proxies are applied to economic indicators by taking the stock sample from KSE during the tenure of 2008-2018. According to past researches and above explanation, it is revealed that Pakistan's economy is small size capital market and high volatile as compared to international markets. Therefore, by focusing on both large and small cap firms the allocation of investment and resources can be done efficiently which would enhance structure of stock market and show visible direction for future investment. Several methodological approaches in terms of market selection and the sample period are employed to assess the association lies between stock market liquidity and economic activity in Pakistan Stock Exchange.

The Significance of this paper is that unique comparative analysis of the stock's market liquidity information content for economic activity primarily focused on Karachi Stock Exchange. This study significantly focuses on large and small cap firms of KSE while previous have not taken that big number of firms. As stock market offers direct funding to the market investors, so they can be considered as an indicator of liquidity for investors in a thriving economy however in a recessing economy it could indicate the negative adjustments of the economy (Nyborg, and Östberg, 2014). Therefore, these factors need to be studied more closely in developing Pakistan so that the information content could be available for local as well as foreign investors.

\subsection{RESEARCH QUESTION}

Following are the research questions

Question 1: What is the relationship of stock market liquidity and economic activity?

Question 2: What factors of stock market liquidity can act as leading indicator for economic activity and vice versa?

\subsection{Outline of the Study}

This research is divided into five chapters. First is introduction that describes the problem statement, significance along with definition of important terms. Second chapter is literature review and hypothesis is developed. The third chapter is research methodology that describes data collection method, sample size and statistical techniques that are being used. Chapter four is results that discuss the finding and their interpretation as well as hypothesis summary. Last chapter is conclusion that also illustrates practical implications along with recommendation for future research work.

Operational Definitions

Stock: A stock is actually a security against corporation's ownership. A stock is also known by the name of 'equity' \& 'shares' (Elliott, 2015).

Liquidity: Liquidity is the extent to which selling or buying of asset or stock can be carried out without disturbing the price of the asset in stock market.

Market liquidity: Market liquidity describes the degree to which selling or buying of assets are bargained at a stable prices (Elliott, 2015).

Macro-economic variables: The variables that affect the economy at country level are macro economic variables. Some of the macroeconomic variables are GDP, inflation rate and employment rate.

Market Volatility: Market volatility is a measure of rise or fall tendency of a market statistically in a defined span of time (Elliott, 2015).

\section{Chapter 2: Literature Review}

The main objective of stock market is to convert investors' savings into more fruitful profits as the savings come from different areas. The stock availability can be determined by macro economic variables as they are the imperative indicators of this. For this sake, portfolio management is introduced so that different macro economic variables are analyzed to assess their impact on the return on stocks.

Globally it is acclaimed that political events even in developing countries cause adverse effect on stock market. However, the extent of these effects can vary on small and large cap firms. Surprisingly, during the 
recession period, large cap firms are not as much affected as small cap firms. Similarly, small cap firms are the ones who benefit more during prosperous times and when the economy is expanding. According to Leirvik et al., (2017) stocks of small cap firms are less liquid as compared to large cap stocks because during economic downturns investors increasingly back out their stocks from small cap stocks performing poorly which are comparatively less liquid than from large cap stocks. According to Cakici \& Tan (2014), a large drop in the liquidity of small cap firms implies that a recessionary period is about to begin. It is a strong signal for investors to switch their investments in stock to large cap stocks or government bonds from small cap. For the sake of avoiding prolonged recessionary period, central banks should act instantly and make funds available for the investors in order to fuel up the real economic conditions.

In a stock exchange when the daily changes is observed it is found that liquidity of small cap firms is usually more affected as compared to large cap firms, therefore it can be stated that daily changes in liquidity tend to affect stock returns in a heterogeneous manner and is dependent on the firm size. The information revealed by the liquidity of small cap firms is more useful to predict future macro fundamentals (Chiang and Zheng, 2015). This is the reason that contributes to the fact that investors move out of small cap firms more quickly as compared to large cap firms and the reason could be the fact that it changes expectations of investors. Another reason could be limitation of increased funding liquidity. This also shows that before recession the trading volume exhibits a larger drop in small cap than in large cap firms.

Literature offers an extensive explanation to provide reasons between the relationship of stock market liquidity and economic growth. However, not much academic researches have been carried out to aggregate market liquidity and the future economic conditions. The following literature follows a pattern of discussing studies that have significant results and then moving on to less significant ones. Kim (2013) conducted a study in Korea with an objective of showing a relationship between stock market liquidity and real economic activity. He collected data during the time duration of 1995:2-2011:4. As a result of this study, strong significant correlation was observed between stock market liquidity and future economic growth in Korea. In this study they found that Amihud illiquidity measure plays a significant role to predict real GDP growth. Further it was found that illiquidity factor in new, small sized, non-dividend-paying, and distressed firms are difficult to arbitrage and tend to be more informational opaque. Moreover, they are informative in predicting future economic downfalls. In a nutsell, it can be concluded that when investors feel that the economy is getting distressed then they transfer their portfolios towards safe assets.

Taking Stock price as an indicator for economic activity, Irfan and Attari (2013) in their research conducted on both developing and developed countries during the tenure from Dec 1991 to Aug 2012.They applied the EGARCH (Exponential Generalized Autoregressive Conditional Heteroskedasticity) to analyze macroeconomic variable like inflation interest rate and GDP in Karachi Stock Exchange 100 Index to test. They used ARCH and ADF to check homoskedasticity and concluded that stock prices are greatly influenced by macroeconomic variables. While taking asset price into account, Goldberg in 2016 investigated shocks by dealer firms to the supply of liquidity and further investigates their impact on real economic activity. For this purpose, he used sign restrictions in a structural VAR model derived from theoretical model and simple theoretical model also to assess the supply liquidity shocks. His result proves that the shocks those are orthogonal to asset price and macro economic variables have significant impact on economic activity. Furthermore, it can be said that positive liquidity shocks can derive huge and stagnant increase in economic real-time activity.

Khan \& Ahmed (2015) conducted a study with the objective of determining the role of variable that affect the stock market in economy. They took stock prices as their independent variable and dependent variables were Imports and Exports of Goods and Services. They collected secondary from Federal Board of Revenue and from State Bank of Pakistan for sample period of 5-years (2005 to 2009). The focus of their research was Karachi Stock Exchange (KSE). Regression analysis was applied to test the hypothesis established. Their study developed a relationship between fluctuation of stock prices and the economic indicators. Therefore, the economic variables change is predicted by the changes in stock market of a country. The changing conditions of stock market are significant for any country as it serves as a guide to the economic activities in future. However, Pakistani stock market always comes under the heating debate of being guided through speculations of the brokers. Many critiques are of the opinion that stock markets in Pakistan are not following the true fundamentals principles. This criticism has strongly been enforced by certain incidents when the economy was showing a graph of upward trend however in reality the situation went against it and stock market experienced great inflation and declined. Macroeconomic and microeconomic variables both have long term effects on stock prices and have the ability to predict the stock market conditions. The role of financial institutions in the economic growth of Pakistan is like a driving force.

Rehman, Mahdzan, and Zainudin (2016) in their study investigate that in emerging market, whether the macroeconomic variables have impact on stock market liquidity claimed that market liquidity in the short-run, interest rate, monetary base and foreign equity new influx had lagged effect. During the period of 2000 to 2014 , they used Granger causality test and IAA (innovative accounting approach) to check the causality with the 
variables of interest. Furthermore, the causality test suggests stock market liquidity is only affected by foreign equity and industrial production. The innovative accounting approach (IAA) concluded that blow to foreign equity net inflow and inflation tends to increase the stock market illiquidity whereas, it also shows that stock market illiquidity tends to decrease when positive shocks were given to industrial production.

Another Study by Lahura \& Vega (2014) showed insignificant relationship between causal effect of stock market on real economic activity. They conducted their study in Peru and collected annual time series data for the tenure of 1965-2013. They applied simple growth model as well as vector autoregressive models on the data. Using these models in the dynamic response of real output per capita, they discovered stock market shocks by imposing long-run restrictions. They found that after 1991 real GDP per capita experienced short-run causal effect by stock market shock. This result was inconsistent with the standards of Granger causality tests. It is to be kept in mind that stock market shocks do not contribute much to output growth dynamics. However, the policy actions upon which Peruvian stock market runs give hope of impacting the dynamics of economic growth positively. The order flow in equity market was closely examined in relation to stock market liquidity in US. The information content of two different measures of order flows in equity market and expected stock returns were analyzed. The result extracted from their research shows that these measures can actually predict economic growth for future of Gross domestic product (GDP) up to four times ahead. Their findings are even valid when associated common equity factors are controlled.

Ogunrinola, et.al (2015) in his study conducted in Nigeria examined the impact on economic growth of Nigeria by stock market liquidity during the tenure of 1980 to 2012. He used econometric software E-view 5.0 and for test for stationarity he used the augmented 'Dickey Fuller approach' whereas, the OLS (ordinary least square) technique was used to examine the estimate of basic model for the research. The results that were revealed by the analysis of data while the co-integration approach by Johansen confirmed the existence of cointegrating relationship at 5\% level of confidence. It could be said that stock market liquidity is insignificant when talking statistically in variables explaining Nigera's economic growth for the same tenure used.

Florackis et al. (2014a) in his study explored the UK market to investigate the importance of stock market liquidity in predicting the real UK market growth. His study mainly focused on macroeconomic activity of UK market in terms of GDP growth. The GDP growth data w was collected for the time duration of 1989-2012. The statistical technique of standard linear and nonlinear models was applied on the data and the result indicated that between stock market illiquidity and future growth in GDP of U.K. is significant negative in relationship. These results were derived after using the explanatory variables like term spreads, real money supply/divisia and shortterm interest rates. When the economic growth is deteriorating and the market conditions are illiquid then the effects of market illiquidity as well as divisia money become strong. Lastly, another out-of-sample forecasting analysis, in the same study that a regime switching model of illiquid vs. liquid market conditions forecasts the growth in GDP of U.K. market even better than the Bank of England's inflation report.

\section{Chapter 3: Research Methods}

\subsection{Method of Data Collection}

The research study at hand extensively relies on secondary data collection. The data was handpicked from the statement of accounts and the annual reports of the selected firms. The data collected from these firms was on the Karachi Stock Exchange for the time duration of 2008 to 2017. Each firm data was the stock prices of monthly closing. These firms were manufacturing industries, textile industries and banks. Their complete details were given in data file. The KSE 100 index was gathered from the websites of Karachi Stock exchange and Business Recorder's website. The data in this study was determined upon their availability on the Karachi Stock Exchange. Sample data was collected for the targeted variables to determine whether stock market liquidity explains real economic activity (Copper \& Schindler, 2014) and vice versa

For putting together the empirical review in the literature section the research projects of last 10 years i.e. from 2008 to 2017 were taken into consideration and made a part of the study. The time duration of ten years was defined in order to maintain the reliability and credibility of our research as in this research 25 companies were taken. This even helped the researcher to have solid grounds by which the liquidity and economic factors are accurately measured. Genuine published studies were gathered from trustworthy journals like Journal of International Money and Finance, Pakistan Journal of Commerce and Social Sciences and International Journal of Monetary Economics and Finance to uphold the reliability of the current research.

\subsection{Sample Size}

The sample for this study consists of 25 that stocks listed on the Karachi Stock Exchange. For the purpose of calculating the liquidity proxies and real economic activity, daily stocks prices data and returns, total number of shares and trading volume of each company were included for the last 10 years (2008-2017). Available stock data was included into the sample.

The data collected from these firms was on the Karachi Stock Exchange for the time duration of 2008 to 
2018. Each firm data was the stock prices of yearly closing. The KSE 100 index was gathered from the websites of Karachi Stock exchange and Business Recorder's website. The data in this study was determined upon their availability on the Karachi Stock Exchange.

\begin{tabular}{|l|c|c|c|c|}
\hline Companies & Turnover & volume traded & real spread & ILR \\
\hline Engro & 17.96 & 21.00 & 0.14 & 6.7 \\
\hline Masood & 16.11 & 1.75 & 0.19 & 5.87 \\
\hline Nbp & 10.82 & 1.75 & 0.09 & 5.7 \\
\hline Agtl & 53.88 & 25.00 & 0.17 & 6.03 \\
\hline Clover & 0.04 & 0.00 & 0.06 & 5.2 \\
\hline Unity & -1.08 & 0.00 & 0.20 & 4.53 \\
\hline ATLH & 45.10 & 27.00 & 0.10 & 5.03 \\
\hline ACPL & 17.96 & 21.00 & 0.14 & 4.62 \\
\hline NATF & 16.11 & 1.75 & 0.19 & 5.09 \\
\hline HBL & 10.82 & 1.75 & 0.09 & 5.35 \\
\hline UBL & 53.88 & 25.00 & 0.17 & 6.78 \\
\hline SUZUKI & 0.04 & 0.00 & 0.06 & 6.7 \\
\hline Nestle & -1.08 & 0.00 & 0.20 & 5.87 \\
\hline Gulahmed & 45.10 & 27.00 & 0.10 & 5.7 \\
\hline MEBL & 17.96 & 21.00 & 0.14 & 6.03 \\
\hline AKBL & 16.11 & 1.75 & 0.19 & 5.2 \\
\hline PSO & 10.82 & 1.75 & 0.09 & 4.53 \\
\hline Shell & 53.88 & 25.00 & 0.17 & 5.03 \\
\hline Dawood & 0.04 & 0.00 & 0.06 & 4.62 \\
\hline MTL & -1.08 & 0.00 & 0.20 & 5.09 \\
\hline FCCL & 45.10 & 27.00 & 0.10 & 5.35 \\
\hline INDU & 17.96 & 21.00 & 0.14 & 6.78 \\
\hline DGKC & 16.11 & 1.75 & 0.19 & 6.7 \\
\hline Fatima & 10.82 & 1.75 & 0.09 & 5.87 \\
\hline KOHC & 53.88 & 25.00 & 0.17 & 5.7 \\
\hline
\end{tabular}

\subsection{Research model}

We used standard linear equation models for the GDP RC.RI, and Unr model for finding the correlation between stock market liquidity and various economic factors as mentioned in the sampling technique. The equation model is given below

$\operatorname{RGDP}=\alpha_{\mathrm{o}}+\beta_{1}\left(\mathrm{ILR}_{\mathrm{it}}\right)+\beta_{2}\left(\mathrm{RS}_{\mathrm{it}}\right)+\beta_{3}\left(\mathrm{TUR}_{\mathrm{it}}\right)+\beta_{4}\left(\mathrm{VTR}_{\mathrm{it}}\right)+\varepsilon_{\mathrm{it}}$

$\mathrm{RC}=\alpha_{0}+\beta_{1}\left(\mathrm{ILR}_{\mathrm{it}}\right)+\beta_{2}\left(\mathrm{RS}_{\mathrm{it}}\right)+\beta_{3}\left(\mathrm{TUR}_{\mathrm{it}}\right)+\beta_{4}\left(\mathrm{VTR}_{\mathrm{it}}\right)+\varepsilon_{\text {it }}$

$\mathrm{RI}=\alpha_{\mathrm{o}}+\beta_{1}\left(\mathrm{ILR}_{\mathrm{it}}\right)+\beta_{2}\left(\mathrm{RS}_{\mathrm{it}}\right)+\beta_{3}\left(\mathrm{TUR}_{\mathrm{it}}\right)+\beta_{4}\left(\mathrm{VTR}_{\mathrm{it}}\right)+\varepsilon_{\text {it }}$

$\mathrm{Unr}=\alpha_{0}+\beta_{1}\left(\right.$ ILR $\left._{\text {it }}\right)+\beta_{2}\left(\mathrm{RS}_{\text {it }}\right)+\beta_{3}\left(\mathrm{TUR}_{\text {it }}\right)+\beta_{4}\left(\mathrm{VTR}_{\mathrm{it}}\right)+\varepsilon_{\text {it }}$

Statistical Technique

The statistical techniques used were based upon the type of data collected and hypotheses formulated. Cointegration ${ }^{1}$, Wald tests and causality test were applied to find correlation between stock market liquidity and real economic activity factors. The main objective of this study was to develop a complete interpretation of the ideas which were the basis of understanding the study while encompassing the specific data. The interpretation of the data was supported by the relevant and clear linkage between stock market liquidity and real economic activity.

To determine the direction of causation between variables, standard (Granger, 1969) structure has been utilized. Jones (1989) expresses that ad hoc selection method for lag length in Granger causality test is better than any statistical method used to determine optimal lag.

\subsection{Liquidity Proxies and Sample Firms}

There are various indicators developed in the literature that are attempted to measure stock market liquidity and economic activity. Since stock market liquidity is an unobservable characteristic of a capital/asset market, which cannot be calculated in a single measure, it is, therefore suggested to explain the issue with the use of a variety of liquidity measures. (Kyriazis, 2015)We use two alternative liquidity measures:

\footnotetext{
${ }^{1}$ The method of co-integration can be used to evaluate the sustainable long-term association between the two selected variables. It implies that the co-integration exists if the prob value is below 0.05
} 
a) Amihud (ILR)

b) the relative spread (RS)

c) Turnover (TUR)

d) the volume of trading (VTR)

They two tools are best to measure liquidity by investment professionals and researchers and also have been previously used in the relevant literature in other characteristic of liquidity like as in asset pricing. Amihud's illiquidity ratio (ILR) is the ratio of absolute stock returns to monetary volume on a daily basis. It shows how much prices moves for each monetary unit of trades. Real Spread (RS ) is an estimated ratio of the quoted spread which is the difference of the best ask and bid quotes over the midpoint price on a daily basis. Whereas, Turnover (TUR) is a widely used measure of activity of liquidity and is calculated as the total no of shares traded during a time period in relation to the number of shares outstanding in the security. In monetary terms the volume of trading (VTR) is calculated when the number of shares traded is multiplied by the concurrent stock price.

\subsection{Macro and Control Variables}

In order to measure real economic activity the macro variables used are as follows:

a) Real GDP (RGDP)

b) Real consumption (RC),

c) Real investment (RI) and

d) The unemployment rate (UnR).

\subsection{Modelling hypothesis methodology}

We used standard linear model for the GDP calculation and regression model for finding the correlation between stock market liquidity and various economic factors as mentioned in the sampling technique.

The research hypotheses are as follows:

H1: There is a significant positive impact of stock market liquidity on real economic activity.

H0: There is a significant negative impact of stock market liquidity on real economic activity.

\section{Chapter 4: Results}

\subsection{Data Summary}

The research is purely secondary in nature. In this research the data was collected through the annual reports of companies listed at Karachi stock exchange. The variables that were chosen in this research were Amihud illiquidity ratio (ILR), the Relative spread (RS), the Turnover (TUR), Volume traded (VTR) were independent variables and Real GDP, Real Consumption, Real Investment, Unemployment rate was dependent variables

Table 4.1

Descriptive Statistics

\begin{tabular}{cllcccr}
\hline S. No. & Variables & Definition & Mean & Std. Dev. & Min. & Max. \\
\hline 1 & ILR & Amihud Illiquidty Ratio & 0.084 & 0.277 & 0.000 & 1.000 \\
2 & RS & Relative Spread & 12.851 & 3.456 & 7.110 & 16.890 \\
3 & TUR & Turnover & 0.431 & 0.248 & 0.000 & 0.9300 \\
4 & VTR & Volume Traded & 4.312 & 2.578 & 1.000 & 12.000 \\
5 & RGDP & Real GDP & 0.119 & 0.055 & 0.000 & 0.2400 \\
6 & RC & Real Consumption & 9.832 & 0.456 & 6.104 & 10.612 \\
7 & RI & Real Investment & 1.108 & 0.869 & 9.213 & 9.189 \\
8 & UNR & Unemployment Rate & 1.092 & 2.147 & 0.000 & 7.118
\end{tabular}

After the descriptive analysis the following table showed the value of mean, standard deviation, minimum and maximum, the mean value of ' ILR (Amihud Illiquidty Ratio) showed mean value which was 0.084 whereas Relative Spread was 12.851, Turnover was 0.431, Volume Traded was 4.312, Real GDP was 0.119, Real Consumption 9.832, Real Investment 1.092 and Unemployment Rate showed mean value which was 1.092.

When checking standard deviation RS, UNR and VTR has showed high standard deviation has lots of variation and fluctuation in the data ILR,TUR,RGDP,RC and RI showed average standard deviation which indicate data has few variations and fluctuation.

\subsection{Unit Root}

In order to assess the long-term relationship, the unit root test was applied. After applied this unit root test the variables were found to be non-stationary at one level, proving the existence of trend; while in contrast, the variables at 1 st diff were found to be stationary, implying no trend.

Since the data was in panel form not the time series so applying unit root so augmented Dickey-Fuller 
(Fisher) was the most appropriate. This test for the most part uses values of p particularly for each cross section. The main benefit of utilizing this test, that it can handle unbalanced panels in the data (Choi, I. 2001).

Table 4.2

Unit Root

\begin{tabular}{|c|c|c|c|c|}
\hline \multicolumn{5}{|c|}{ UNIT ROOT TEST - AUGMENTED DICKEY FULLER (ADF) } \\
\hline & \multicolumn{2}{|c|}{$\mathbf{I}(\mathbf{0})$} & \multicolumn{2}{|c|}{ I(1) } \\
\hline & $\mathbf{C}$ & $\mathbf{C} \& \mathbf{T}$ & $\mathbf{C}$ & $\mathbf{C \& T}$ \\
\hline Variables & P. Value & P. Value & P. Value & P. Value \\
\hline ILR & 0.0897 & 0.0002 & 0.000 & 0.002 \\
\hline RS & 0.0041 & 0.0132 & 0.000 & 0.000 \\
\hline TUR & 0.1229 & 0.0373 & 0.000 & 0.002 \\
\hline VTR & 0.9072 & 0.6756 & 0.000 & 0.000 \\
\hline RGDP & 0.655 & 0.616 & 0.002 & 0.000 \\
\hline $\mathrm{RC}$ & 0.474 & 0.442 & 0.000 & 0.002 \\
\hline & 0 & & & \\
\hline RI & 1229 & 0.0373 & 0.000 & 0.002 \\
\hline UNR & 0.9072 & 0.6756 & 0.000 & 0.000 \\
\hline
\end{tabular}

First the all given variable was tested at trend so the data was found non stationary since $\mathrm{p}$ value was greater than 0,5 then after applied $1^{\text {st }}$ difference the variable at level since $p$ value was less than 0.5 which means data is stationary and hence no trend was found .

\subsection{Co-integration Test}

In order to evaluate the relation of variables in the long run the co-integration test was applied co-integration which was the method of Johansen and Juselius (1990) has been utilized for the objective of this research. The data was further gone through after the unit root. So if the Prob-value is less than 0.5 discovered, for that reason, it is found that the co-integration between the variables exist.

In order to analyze the correlation between variable in the long term as applied co-integration there are three types of methods. The three types of methods are Fisher, Pedroni, and Kao test which comes in the tree of cointegration test. Above all for this panel data Pedroni test has been applied in this study.

\begin{tabular}{lcccc}
\hline Test Summary & Statistic & Prob. & Statistic & Prob. \\
\hline Panel v-Statistic & -2.055465 & 0.9801 & -3.384637 & 0.9996 \\
Panel rho-Statistic & 4.413196 & 1.0000 & 4.367783 & 1.0000 \\
Panel PP-Statistic & -3.425276 & 0.0003 & -9.018198 & 0.0000 \\
Panel ADF-Statistic & 3.146331 & 0.0041 & -0.267714 & 0.3945 \\
Group rho-Statistic & 6.222282 & 1.0000 & & \\
Group PP-Statistic & -18.81486 & 0.0000 & & \\
Group ADF-Statistic & -2.058970 & 0.0197 & & \\
\hline
\end{tabular}

The below table analyzed the co-integration between the dividend policy and stock price volatility. After the analysis it was observed that is 4 co-integrations were found between Stock liquidity and macro economic variables since P value $(<0.1)$ at Panel PP statistics, Panel ADF Statistics and on Group PP statistics and Group ADF statistics.

\subsection{Wald Test}

To enhance the robustness of these findings, we further test whether there is a difference between the coefficients of the liquidity proxies for companies listed at Karachi stock exchange by performing the Wald tests in Table 4.4. For each measure, we first test the null hypothesis that the difference between the liquidity proxy for companies is equal to zero (Panel A) and then test the null hypothesis that the difference between the illiquidity measure for companies is greater than zero (Panel B). The results obtained indicate that across all macro variables, the liquidity coefficient firms is statistically significant, indicating the larger effect of firm. previous studies (e.g. Amihud, 2002; Naes et al., 2011; Cakici and Tan, 2014). Thus, it is important for investors and central bank authorities to watch closely for a large drop in the liquidity of firms stocks, as long as it gives a strong signal for the beginning of a recessionary period. As investors may start switching from their positions on to government bonds or large cap stocks, central banks may increase promptly the money supply aiming to stimulate the real economy and hence to avoid plunging in a deep and prolonged recession. 
Table 4.4

Correlated Random Effects - Wald Test

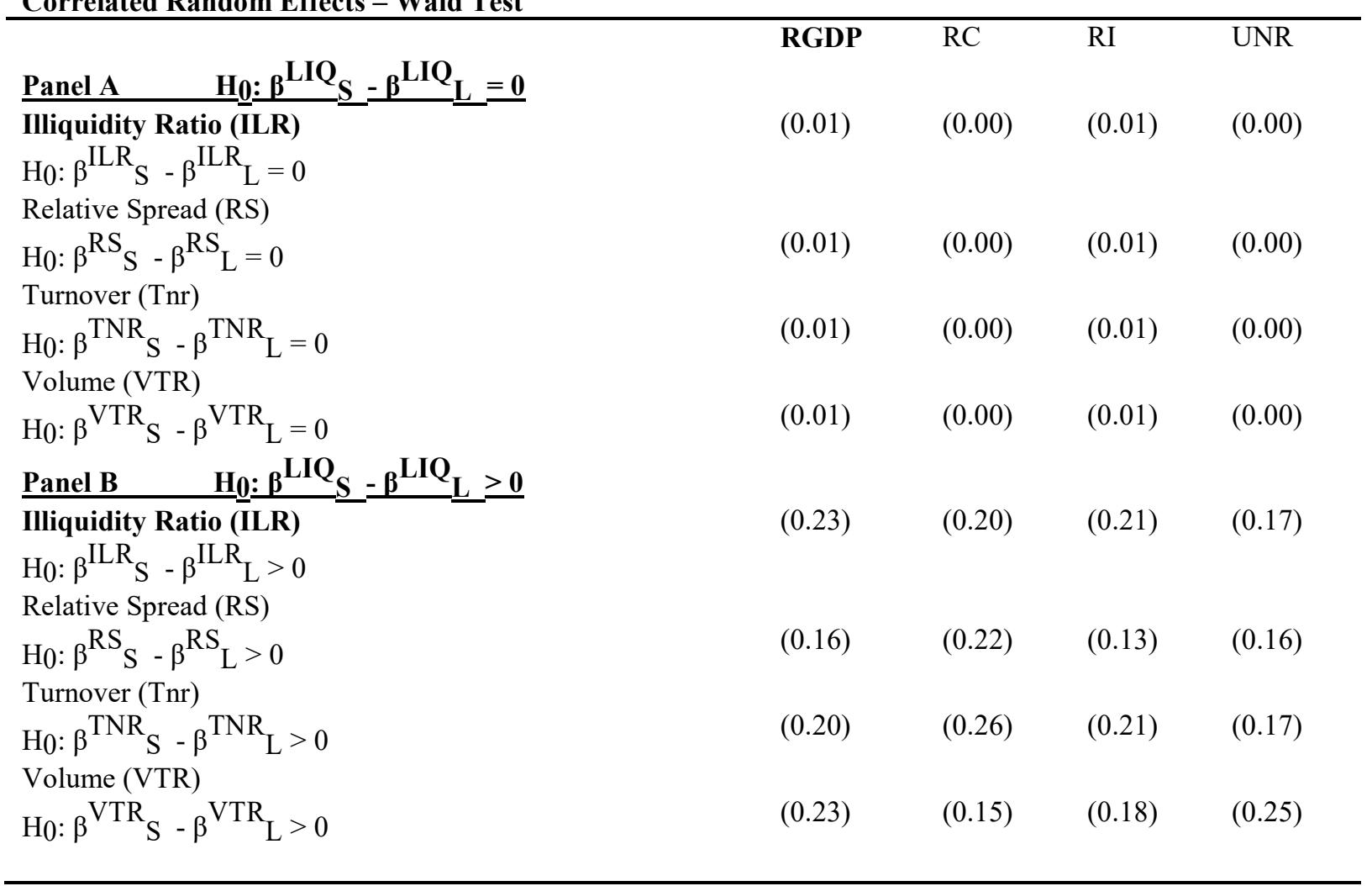

\subsection{Causality Test}

The causality results, reported in Table 6, display that in companies listed at stock markets there exists a oneway causality running from both the illiquidity ratio (ILR) and the relative spread (RS) to all four alternative macroeconomic variables $(\triangle \mathrm{MACRO})$. These findings are compatible with the forward-looking nature of liquidity related to the stock market as documented by Fama (1991). In addition, it recognizes the importance of market liquidity as a component of the financial system in the process of economic growth, gaining further support by the argument put forward by Levine and Zervos (1998). In particular, market liquidity is important to restore the confidence of investors in the value of information associated with trading. Therefore, investors, in the case of increases in market liquidity, are encouraged to invest more heavily, increasing the flow of capital, leading to further increases in economic activity

By contrast, for the turnover and the trading volume liquidity indices this one-way causality holds only in the cases of investment and the unemployment rate in both countries. The presence of two-way causality denotes that the growth process itself nurtures the growth growth levels provide a boost both to the stock market and to the liquidity measures associated with it.

Our findings tend to be consistent with the findings by Naes et al. (2011) who document that for the whole sample period there is full support for Granger one-way causality from market illiquidity/liquidity proxies (ILR, implicit spread estimator of Roll, the LOT measure) to GDP, while no reverse causality from GDP to these proxies is present.

These results are also consistent with the argument put forward by Levine and Zervos (1998) and Rousseau and Wachtel (2000), according to which, market liquidity is related to economic growth. As investors are encouraged by high market liquidity to invest in equities and increase the flow of capital, such moves would efficiently allocate resources and, hence, enhance economic growth in the long run. The causality empirical findings display that stock markets can effectively mobilize funds that have been not fully absorbed by financial intermediaries into productive investments and, hence, spur economic growth. 


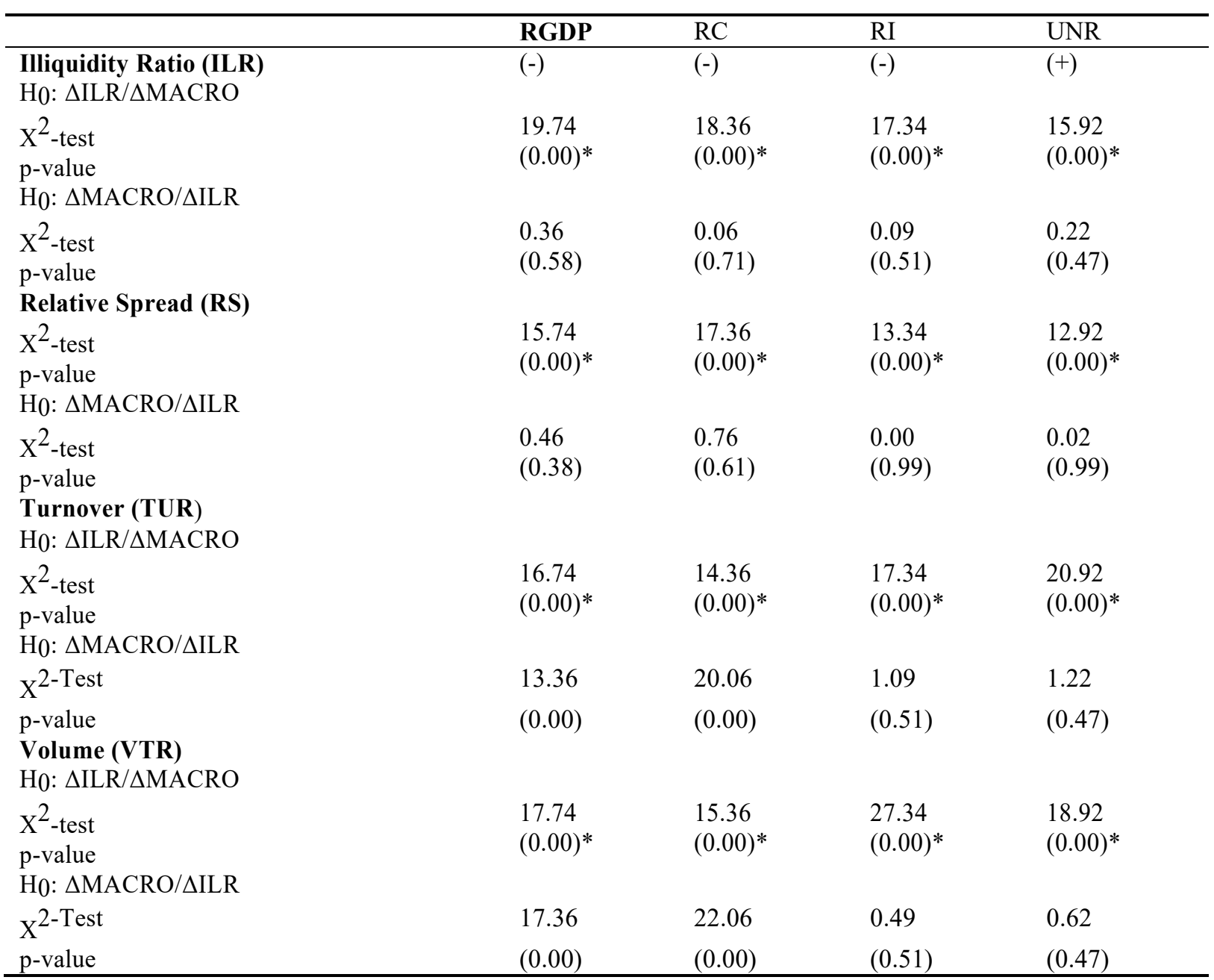

\section{Chapter 5 Conclusion}

The research was conducted in detail and on the information content in economic conditions of Karachi stock exchange KSE in terms of stock market liquidity. This study is an attempt to fill the research gap highlighted in the beginning. Companies listed in KSE are huge in terms of market capitalization, this is the reason that KSE was taken for this study in order to produce strong and widely applicable results. The empirical findings suggest that stock market liquidity and economic factors were highly correlated and associated in Karachi Stock Exchange 100-index. Our findings suggest that in case of mature funds especially the mechanism through which the funds are injected either through banks or capital markets is not of much significance. The course on which the macroeconomic variables flow in small- cap firms turned out to be more important that in large-cap firms in terms of market liquidity in Karachi Stock Exchange. Therefore, the trend drives investors to expand their portfolios from small-cap firms illiquid firms to the large-cap firms which are more liquid and stable when considering future economic perspectives. The small-cap firms, in our study turned out to be more illiquid as their stock fluctuate more in stock market as compared to large-cap firms who are more stable in terms of stock price fluctuations and can be liquefied easily.

The empirical findings of the current study emphasizes on the importance of market liquidity and its role that it plays in the process of economic growth. The relationship becomes further significant during the phases of turbulence and time of recession of economy. The findings of this study propose that the liquidity has a close relation with both the funding liquidity risk as well as the market liquidity risk. The market liquidity risks prevail due to the worsening condition of market liquidity and trade becomes necessary for the potential investors of the market. Whereas, funding liquidity risk force the investors to wind down their investments as the door for trading closes for them and it becomes out of option. The real economy is affected by such perverse situations significantly. The real economy and the financial systems are affected by market liquidity and any false activity or disturbance can cause financial crises that can make the financial conditions unstable and negatively affect the resources allocation. The funding liquidity of investors need to be enhanced as suggested by the downward liquidity trend in the market. Our findings further recommend that for small firms the asset price factors cannot significantly forecast the economic growth (Sharif and Afshan, 2016). They can only affect when 
mutual flow of international long-term interest rates is affected. Further it is suggested that the stock market liquidity has become a relevant predictor of economic activity as compared to time spread. This condition is in contrast to what was happening during the last century.

The following recommendation are made here. The first and the foremost step could be removal of additional barriers such as legal implications, taxes and over regulatory steps. During the crucial and critical events, the importance and significance of monetary policies by the monetary authorities cannot be ignored which employ and implement efficient monetary policies to ensure stability in capital markets as it is well aware fact that illiquidity among stock markets are high during such crucial periods. The primary role to maintain the stability and liquidity levels among stock markets lie with the central banks or in case of Pakistan the State Bank to pacify and secure the investments of big investors so that they may hold their stock for the longer period of time. During these times efficient cuts in interest rates or other macro economic factors are to be done by the central body to encourage major market participants to hold their investments as they are affected by the deteriorating factors of economy and they may shift to 'safety' from 'flight' effect. These participants may trade in government bonds instead of stocks or they may buy shares from small-cap firms that from large-cap firms, stocks to more liquid ones in such times that their damages from longer investments could be controlled.

The results of our study could be beneficial for managers of corporate sectors and policy makers as they can get the idea of allocating their resources in an improved manner. These results can help them to improvise the real economic activity conditions by making use of stock market liquidity confidently. No investments come without the risk factor, however, when the capital markets with enough liquidity strength can be expected to have minimum associated risks. The decrease in associated risks can enable the savers to adopt the equities which are sold in a fast manner. This will not incur high costs even if they require making changes in their portfolios. Along with resource allocations, the capital allocation will also be carried out efficiently in overall improved and more functional stock market liquidity. This in return is also expected to bring more investments in the economy. Moreover, the companies with illiquid markets for their stocks are prone to more external shocks. Therefore, through providing liquidity to the stock market, the risk associated with them can be substantially reduced that are faced by the investors and furthermore, this trend would lead to cost reductions in equity market in fund raising to future growth of economy.

The research study can be made more extensive by adding more portfolios from developed countries and/or with countries with stock markets that are not fully developed and popular globally to get more evidences on stock market liquidity relationship with economic activity. This would provide further insight into the relation of economic conditions and stock market liquidity factors and as to how they are interlinked with one another. The need of future researches cannot be emphasized enough. Another suggestion for future researchers is to work on highlighting the factors that play role in affecting the stock market liquidity directly. Therefore, future researches can further identify the indirect macroeconomic activities such as regulatory, accounting, and political, tax, legal and other macroeconomic factors. Lastly, any of these factors can be further analyzed to forecast their relationship between macroeconomic environment and market liquidity.

\section{References}

Blanchflower, D.G., Oswald, A.J., (2013). Does high home-ownership impair the labor market? NBER Working Paper, No. 19079. National Bureau of Economic Research

Boubaker, H. and Raza, S. A. (2016). On the dynamic dependence and asymmetric co-movement between the US and Central and Eastern European transition markets. Physica A: Statistical Mechanics and its Applications, 459, 9-23.

Cakici, N., Tan, S. (2014) Size, value, and momentum in developed country equity returns: Macroeconomic and liquidity exposures. Journal of International Money and Finance 44,179-209.

Leirvik, T., \& Fiskerstrand, S. R. \& Fjellvikås, A.B. (2017).Market liquidity and stock returns in the Norwegian stock market, Finance Research Letters, Elsevier, vol. 21(C), pages 272-2

Cakici, N., Tan, S., (2014). Size, value, and momentum in developed country equity returns: Macroeconomic and liquidity exposures. Journal of International Money and Finance 44, 179-209.

Cooper, D. and Schindler, P. ( 2013) Business Research Method, $12^{\text {th }}$ edition, McGraw-Hill Higher Education,

Creswell, J. W. (2014) Research Design: Qualitative, Quantitative, and Mixed Methods Approaches. 4th ed. Thousand Oaks, California: SAGE Publications,

Chiang, T. C., Zheng, D. (2015) Liquidity and stock returns: Evidence from international markets, GLOBAL FINANCE JOURNAL, DOI: 10.1016/j.gfj.2015.04.005

Amer Al-Jaifi, H., Hussein Al-rassas, A., Ali AL-Qadasi, A. (2017) Corporate governance strength and stock market liquidity in Malaysia, International Journal of Managerial Finance, Vol. 13 Issue: 5, pp.592-610, https://doi.org/10.1108/IJMF-10-2016-0195

Elliott, D. J. (2015) Market Liquidity: A Primer, The Brookings Institution, Economic Studies, data retrieved from https:/www.brookings.edu/wp-content/uploads/2016/07/Market-Liquidity.pdf 
Florackis, C., Giorgioni, G., Kostakis, A., Milas, C., (2014a). On stock market illiquidity and real-time GDP growth. Journal of International Money and Finance 44, 210-229.

Florackis, C., Giorgioni, G., Kostakis, A., Milas, C., (2014a). On stock market illiquidity and real-time GDP growth. Journal of International Money and Finance 44, 210-229.

Florackis, C., Kontonikas, A., Kostakis, A., (2014b). Stock market liquidity and macroliquidity shocks: Evidence from the 2007-2009 financial crisis. Journal of International Money and Finance 44, 97-117.

Goldberg. J, (2016) The Supply of Liquidity and Real Economic Activity, data retrieved from https://www.aeaweb.org/conference/2017/preliminary/paper/zB34aSet

Irfan, M., Attari, J. (2013). The Relationship between Macroeconomic Volatility and the Stock Market Volatility: Empirical Evidence from Pakistan. Pakistan Journal of Commerce and Social Sciences, Vol. 7, 12.

Karamujic, H.M., (2013). Building approvals as a leading indicator of property sector investment. International Journal of Banking and Finance 9, 44-58.

Khan. K \& Ahmed. I, (2015) Impact of Stock Prices on Macroeconomic Variables: Evidence from Pakistan Lecturer data retrieved from https://kasbit.edu.pk/KBJVol8-1/chap42-59.pdf

Kim. J, (2013) How does Stock Market Liquidity Forecast Economic Growth? European Journal of Business and Management www.iiste.org ISSN 2222-1905 (Paper) ISSN 2222-2839 (Online) Vol.5, No.31, 2013, data retrieved from https://www.iiste.org/Journals/index.php/EJBM/article/download/9478/9678

Lahura. E and Vega. M, (2014) Stock Market Development and Real Economic Activity in Peru, data retrieved from http://www.bcrp.gob.pe/docs/Publicaciones/Documentos-de-Trabajo/2014/documento-de-trabajo-222014.pdf

Nyborg, K.G., Östberg, P., (2014). Money and liquidity in financial markets. Journal of Financial Economics $112,30-52$.

Ogunrinola et. 1, (2015) Stock market liquidity and economic growth in Nigeria (1980 to 2012), data retrieved from http://eprints.covenantuniversity.edu.ng/5788/1/JEIBM(Sept.\%202014)154\%20Ifeoluwa\%20(1).pdf

Rehman, I, Mahdzan, S. N. And Zainudin, A. (2016) Is the relationship between macroeconomy and stock market liquidity mutually reinforcing? Evidence from an emerging market, International Journal of Monetary Economics and Finance, 2016 Vol.9 No.3, pp.294 - 316

Rehman. Et. al, (2016) Is the relationship between macroeconomy and stock market liquidity mutually reinforcing? Evidence from an emerging market Int. J. Monetary Economics and Finance, Vol. 9, No. 3, data retrieved from https://umexpert.um.edu.my/file/publication/00008277_126460_62929.pdf

Sharif. A. A \& Afshan. S., (2017) Impact of Stock Market on Economic Growth of Pakistan Data retrieved from https://www.researchgate.net/publication/316648101_Impact_of_Stock_Market_on_Economic_Growth_of Pakistan

Yin, K.R. (2014). Case Study Research Design and Methods (5th ed.). Thousand Oaks, CA: Sage. 282 pages.

Apergis, N., Artikis, P. G., \& Kyriazis, D. (2015). Does stock market liquidity explain real economic activity? New evidence from two large European stock markets. Journal of International Financial Markets, Institutions and Money, 38, 42-64.

Czauderna, K., Riedel, C., \& Wagner, N. (2015). Liquidity and conditional market returns: Evidence from German exchange traded funds. Economic Modelling, 51, 454-459.

Argamaya, A. (2014). Economic Trends and Macroeconomic Management In Indonesia: 1960s-1980s. Business and Management Review, 3(1).

ARTIKIS, P. G. (2018). LIQUIDITY AS AN ASSET PRICING FACTOR IN THE UK. Journal of Financial Management, Markets and Institutions, 1850008. 